\title{
Abundance and Diaspore Weight in Rare and Common Prairie Grasses
}

\author{
Deborah Rabinowitz \\ Division of Biological Sciences, University of Michigan, Ann Arbor, MI 48109, USA
}

\begin{abstract}
Summary. Abundance $\left(\mathrm{g} / \mathrm{m}^{2}\right)$ and diaspore weight are positively correlated in seven species of perennial grasses that occur in prairies. The rare grasses $\left(<10.0 \mathrm{~g} / \mathrm{m}^{2}\right)$ have light dispersal units $(0.06$ to $1.76 \mathrm{mg})$; the common grasses $\left(>10.0 \mathrm{~g} / \mathrm{m}^{2}\right)$ have heavy dispersal units $(2.23$ to $2.80 \mathrm{mg})$. This result is the first reported differentiating trait between related rare and common organisms occurring in same habitat.

Three hypotheses that explain this phenomenon are compared; the third most likely holds. First, rare grasses may be rare because their small seeds are less successful in establishment than those of common grasses. Second, if the persistence of small populations is marginal, rare grasses may devote less energy (or other currency) to seed production. Third, rare grasses may be colonizers of spatially and temporally rare microsites appropriate for growth and thus have seeds adapted for longer distance dispersal than those of common grasses. This last hypothesis suggests a new pathway for the evolution of weeds.
\end{abstract}

\section{Introduction}

The persistence of rare species is a puzzling phenomenon. Understanding the dynamics of sparse populations is critical to explaining the coexistence of species in diverse communities such as temperate grasslands and tropical forests. Life history characteristics that differentiate related sympatric rare and common plants may show how small populations persist despite the disadvantages associated with small deme size. Reported here is a trait distinguishing rare species from common relatives: a positive correlation of abundance and diaspore weight in seven species of prairie grasses.

\section{Materials and Methods}

The species studied are perennial grasses native to tall grass prairie (Weaver, 1954) and other habitats (Hitchcock, 1950). Three of the species are typical "dominants" in tall grass prairie: Andropogon gerardi Vitman, A. scoparius Michx. (=Schizachyrium scoparius [Michx.] Nash), and 
Sorghastrum nutans (L.) Nash. These are panicoid grasses in the tribe Andropogoneae (Gould, 1968), and all are warm season C4 perennials (Teeri and Stowe, 1976).

The four rare species are not dominants in any habitat. Their geographic ranges are large; they are frequently found but characteristically in low density. I term these sparse species to distinguish from endemic rarity, in which species have small geographic distributions but are usually locally common. The sparse grasses are Agrostis hiemalis (Walt.) B.S.P., Sphenopholis obtusata (Michx.) Scribn., Festuca paradoxa Desv., and Setaria geniculata (Lam.) Beauv. The first three are festucoid, cool season C3 grasses; $S$. geniculata is a C4 midseason panicoid grass.

The study site is Tucker Prairie Research Area, a 65 ha remnant of tall grass prairie on which the sod has never been turned. The preserve, in Callaway County, Missouri, USA, is burned on an approximately four year rotation.

Weights of single dispersal units were determined on a Cahn electrobalance. First, single diaspores from bulk collections of mature propagules were weighed $(N=30)$. Bulk collections contain a mixture of diaspores that do and do not contain caryopses (= grains). Second, single diaspores containing a mature grain were weighed $(N=50)$. Third, excised caryopses without accessory tissue were weighed $(N=50)$.

Morphology of the dispersal unit varies among the species. Festuca paradoxa and Agrostis hiemalis disarticulate above the glumes, dispersing the grain, the lemma and palea. Spikelets of Sphenopholis obtusata have two florets. The uppermost floret disarticulates without the glumes; the lower disarticulates below the glumes. In Setaria geniculata, the entire spikelet disperses. In Sorghastrum nutans, Andropogon gerardi, and A. scoparius, the dispersal unit consists of a pair of one-flowered spikelets, one of which is sterile, plus the rachis joint.

Abundance was measured as standing crop of live material. Plants with bases within the quadrat were clipped at soil level, sorted according to species, oven-dried at $80 \mathrm{C}^{\circ}$ for $24 \mathrm{~h}$, and weighed. Data were collected in three $10 \times 30 \mathrm{~m}$ areas with $300.10 \mathrm{~m}^{2}$ samples in each during June, July and early August, 1977. One-way analysis of variance on the total standing crop (all graminoids plus forbs) in the three groups failed to show significant differences among the groups $\left(F_{s}=2.30, F_{.05}(2,90)=3.10\right)$, and thus the data for the three areas were lumped.

\section{Results}

The three dominants comprise $40 \%$ of the total above ground biomass and $60 \%$ of the graminoid biomass in a community of 240 species (40 of which are grasses). The four sparse species comprise $2.7 \%$ of the total biomass and $4.0 \%$ of the graminoid biomass.

The logarithm of abundance and mean weight of dispersal units are linearly correlated (Fig. 1). Sparse grasses have smaller dispersal units than common grasses. This relationship holds for samples of diaspores that contain a mixture of full and empty florets (Fig. 1 a), diaspores with caryopses (Fig. 1 b), and excised caryopses (Fig. 1 c).

Because of the graminoid growth form, it is not possible to distinguish genetic (or physiologic) individuals in the field. Thus, differences in biomass of the species are employed to approximate differences in the abundance of individuals. Because the range in biomass from the most common (Andropogon scoparius at $73.0 \mathrm{~g} / \mathrm{m}^{2}$ ) to the most sparse (Sphenopholis obtusata at $0.25 \mathrm{~g} / \mathrm{m}^{2}$ ) spans nine octaves (Preston, 1962a, b) or nearly four orders of magnitude, the range abundance of individuals undoubtedly spans at least several orders of magnitude. The weight of individual culms of the common grasses is greater than that of the sparse grasses but not by more than one order of magnitude. Thus, the correlation of abundance and diaspore weight is not an artificial scaling phenomenon of individual plant size (i.e., elephants have larger offspring than mice). 

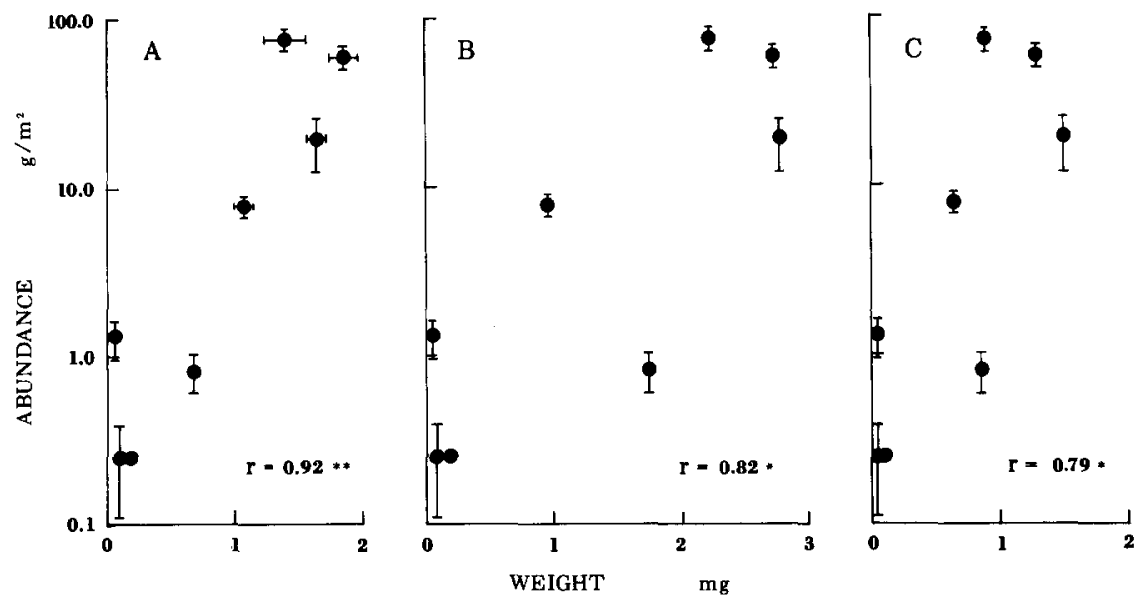

Fig. 1A-C. Three correlations of diaspore weight $(\mathrm{mg})$ with biomass abundance $\left(\mathrm{g} / \mathrm{m}^{2}\right)$ for each species are shown (mean \pm standard error; when no bar is shown, s.e. falls within the circle). A shows the weight of diaspores in bulk collections, which contain a mixture of dispersal units with and without grains (=caryopses), $N=30$. B shows the weight of diaspores with a grain inside, $N=50$. C shows the weight of excised caryopses without accessory tissues, $N=50$. Two points are shown for Sphenopholis obtusata in each figure because the species disperses two types of diaspores; the s.e. for abundance is shown only once. Correlation coefficients are shown; a single asterisk indicates $P<0.05$, double asterisks, $P<0.01$

\section{Discussion and Conclusions}

These results demonstrate that, within a group of related species of the same habitat, the common species have heavy dispersal units, and the sparse species have light ones. There are three hypotheses to account for this fact.

My goal is to present explanations that would readily occur to most ecologists and to argue, on logical and empirical grounds, that the third is most likely to hold. This discussion bears on attitudes toward sparse populations and hopefully sheds light on general ecological properties of rare species. Two of the hypotheses are causal inverses of each other: first, rare grasses are rare because they have small seeds; second, rare grasses have small seeds because they are rare. Both ideas assume that rare species are unsuccessful or disadvantaged in some way. The third hypothesis (that seed size is related to dispersal capacity) is based on the assumption that natural selection can act to favor traits that offset the disadvantages inherent in small deme size (Wilson, 1963). Because we know that many species are rare (Preston, 1962a, b; Williams, 1964) and yet persist successfully, the latter assumption is the more realistic one.

A first hypothesis is that rare grasses are rare because their seeds are small and thus disadvantaged in establishment. Within grass species of agronomic importance, large seed size is associated with increased seedling vigor (McKell, 1972; Kneebone, 1972). In intra- and inter-specific competition experiments, seedlings arising from smaller seeds are competitively disadvantaged (Black, 1958; Harper and Clatworthy, 1963; Williams et al., 1968).

In natural populations, however, such a phenomemon would produce either extinction of the small-seeded populations or selection for greater seed size. 
In addition, small seeds have potentially compensatory advantages, one of which is that they may germinate more rapidly. In the greenhouse, the sparse grasses begin germination in from six to eight days, but the common begin after ten days. Order of emergence in dense swards has a strong influence on the eventual size attained by an individual (Harper, 1977). Ross and Harper (1972) showed for populations of Dactylis glomerata that rank in emergence order accounted for $95 \%$ of plant weight, and the advantage attained by early germination was far greater than could be attributed to the extra days of growth. Thus, the earlier germination associated with small seeds may permit pre-emption of newly available sites. For these reasons, the hypothesis that rarity is a consequence of small seed size in unlikely.

A second hypothesis is that, if small populations are precarious in their persistence, a tenet of island-biogeographic theory (MacArthur and Wilson, 1968), they may be marginal energetically or in terms of some other currency (for instance, garnering of particular nutrients). Thus, they may not have sufficient reserves to produce large seeds. This idea implies that the individuals in a small population have undergone an evolutionary adjustment to marginal persistence: an evolutionary "decision" has been made to produce large numbers of seeds at the expense of their size, as opposed to producing fewer but larger seeds.

A positive correlation of abundance and total weight of diaspores per flowering culm (the unit bearing inflorescences) would indicate reproductive limitation of sparse species relative to common. Culms of the common grasses undergo floral initiation and internode elongation when the number of leaf blades reaches a critical value; below this number, the culms remain vegetative (Rice, 1950). As flowering units, culms appear to act independently of one another, despite possible vegetative connections among them, and thus culms are the natural unit to employ in measuring reproductive output. Reproductive output here is defined as the weight of reproductive material (embryonic plus accessory) per culm and is calculated as the number of diaspores per culm times the mean weight of the diaspore times seed set (Fig. 2). There is no evidence of a correlation of abundance and this rough measure of reproductive investment $(r=0.12$, not significant). Thus there is no support for the notion that rare grasses are more limited than common grasses in the amount of energy (or other currency) available for investment in seeds. The hypothesis that sparse species produce small seeds because their persistence is precarious is rendered unlikely.

A third hypothesis to account for the correlation of abundance and diaspore size is that the smaller dispersal units of the rarer grasses are adapted to longer distance dispersal than those of the common grasses. If habitat patches appropriate for the colonization of the rarer species are themselves rare, far apart, and unpredictable in their spatial and temporal origins, then small, light dispersal units would be required to sample the environment for these sites. Small-scale disturbances of soil such as worm castings, ant hills, and mammal diggings are examples of such open microsites.

The role of environmental patchiness and dispersal in permitting coexistence of species has been demonstrated (or strongly implicated) in theoretical work 


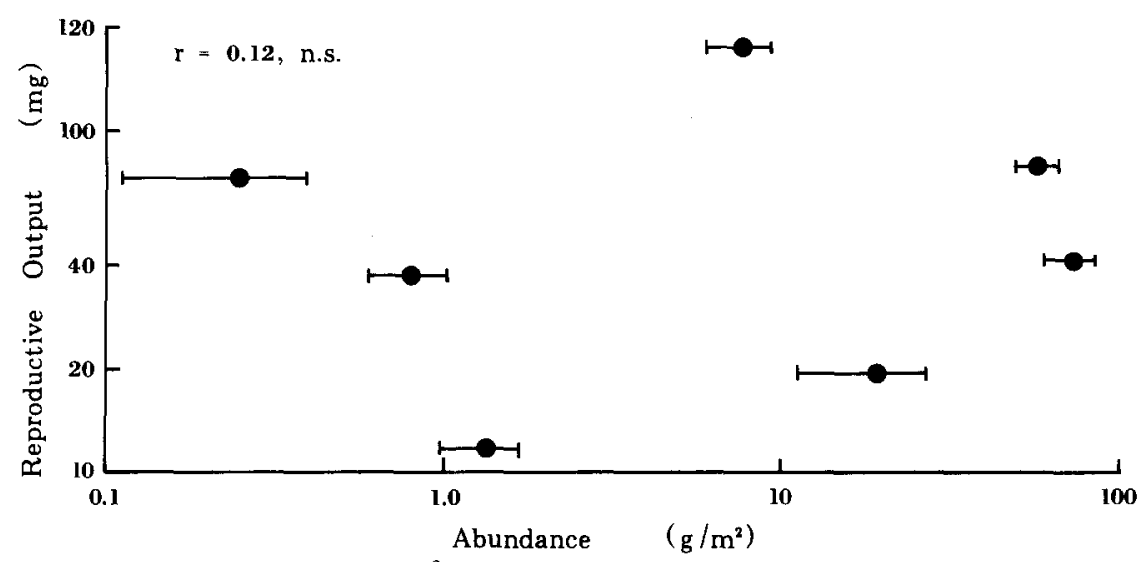

Fig. 2. Biomass abundance $\left(\mathrm{g} / \mathrm{m}^{2}\right)$ for each species is plotted against reproductive output per culm (mg), mean \pm standard error. S.E. for reproductive output falls within the circles. Reproductive output is calculated as the mean number of fertile florets per culm times the mean weight of a diaspore containing a grain times the seed set. The correlation coefficient is shown; n.s. indicates that the $r$ value is not significant

(Skellam, 1951; Levins and Culver, 1971; Horn and MacArthur, 1972; Levin, 1974, 1976; Levin and Paine, 1974; Slatkin, 1974) and in empirical studies in plant communities (Jalloq, 1975; Platt, 1975; Platt and Weis, 1977; King, $1977 \mathrm{a}, \mathrm{b}, \mathrm{c}$ ) and in other ecosystems as well (Dayton, 1971, 1975).

Thus, the rare grasses may exhibit dispersal behavior in common with fugitive species (Salisbury, 1942; Harper et al., 1969; Baker, 1974). The association of rare plants and weeds in natural disturbances was noted decades ago by Griggs (1940). If dispersal to disturbed microsites is a characteristic of some rare species, they are likely candidates for the progenitors of contemporary weeds. Their dispersal mode would preadapt them for association with human disturbance. Some native plants of California, such as Grindelia camporum, may have evolved by this pathway from their formerly restricted habit to their present weedy state (Stebbins, 1965).

Three of the four species of the sparse grasses have numerous congeners which are plants of agronomic importance or are serious weedy pests (Kucera, 1961; Spedding, 1971; Duffy et al., 1974). Examples are Agrostis stolonifera, A. alba, A. tenuis, Festuca rubra, F. ovina, F. eliator var. arundinaceae, Setaria faberii, $S$. viridis, and $S$. italica. The common grasses have few weedy congeners.

One of the sparse species, Setaria geniculata, has made the transition from sparse populations to weediness in some portions of its range in Mexico (deWet and Harlan, 1975). In this case, the evolutionary pathway is known (Callen, 1965, 1967). S. geniculata was an important wild cereal in the Valley of Mexico and Tamaulipas before the advent of corn agriculture. This sparse species was selected for association with human disturbance, to which its dispersal mode may have conferred preadaptation. Where it is common presently, S. geniculata is an ancient abandoned domesticate. 
If we posit that the sparse species persist as ephemeral colonists to disturbances, we cannot therefore conclude that habitat restriction to open patches is the cause of low abundance. That is, if sparse species behave as fugitives, we have not "explained" the rarity, even though abundance may be strictly proportional to site availability. This is so because the fugitive behavior may be a shift in life history characteristics in response to totally different (and unknown) factors (Antonovics, 1976). For instance, suppose that a species is subject to a hypothetical but lethal fungal pathogen. The species may respond by evolving resistence to the pathogen (and perhaps becoming common) or by evolving a life history which permits it to escape the pathogen. Fugitivity in space would be an example of the latter type of response, but in actuality, the pathogen would be the cause of the sparseness. Thus, understanding how sparse species persist in natural communities may tell us how communities are assembled but cannot tell us directly why species assume the abundances they exhibit.

Acknowledgements. This research was supported by a Rackham Faculty Research Grant from the University of Michigan and a grant from the National Science Foundation (DEB 78-11179) and was carried out while I was a Visiting Assistant Professor at the University of Missouri. I thank Clair L. Kucera for advice and encouragement and Barbara Bassett, Gregory Renfro, Coleen Kelly, and Jody Rapp for help in the field. E.G. Leigh, Jr., R.T. Paine, and D.S. Simberloff made helpful comments on the manuscript.

\section{References}

Antonovics, J.: The input from population genetics: The new ecological genetics. Syst. Bot. 1, $233-245(1976)$

Baker, H.G.: The evolution of weeds. Ann. Rev. Ecol. Syst. 5, 1-29 (1974)

Black, J.N.: Competition between plants of different initial seed sizes in swards of subterranean clover (Trifolium subterraneum L.) with particular reference to leaf area and the light microclimate. Aust. J. Agric. Res. 9, 299-318 (1958)

Callen, E.O.: Food habits of some pre-Columbian Mexican Indians. Econ. Bot. 19, 335-343 (I965)

Callen, E.O.: The first New World cereal. Amer. Antiq. 32, 535-538 (1967)

Dayton, P.K. : Experimental evaluation of ecological dominance in a rocky intertidal algal community. Ecol. Monogr. 45, 137-159 (1975)

Dayton, P.K.: Competition, disturbance, and community organization: The provision and subsequent utilization of space in a rocky intertidal community. Ecol. Monogr. 41, 351-389 (1971)

Duffy, E., Morris, M.G., Scheail, J., Ward, L.K., Wells, T.C.E.: Grassland ecology and wildlife management. London: Chapman and Hall 1974

Gould, F.W.: Grass systematics. New York: McGraw-Hill 1968

Griggs, R.F.: The ecology of rare plants. Bull. Torrey Bot. Club 67, 565-594 (1940)

Harper, J.L.: Population biology of plants. London: Academic Press 1977

Harper, J.L., Clatworthy, J.N.: The comparative biology of closely related species. VI. Analysis of growth of Trifolium repens and T. fragiferum in pure and mixed population. J. Exptl. Bot. 14, 172-190 (1963)

Harper, J.L., Lovell, P.H., Moore, K.G.: The shapes and sizes of seeds. Ann. Rev. Ecol. Syst. 1, 327-356 (1970)

Hitchcock, A.S. : Manual of the grasses of the United States, 2nd ed. Washington, D.C.: U.S.D.A. 1950

Horn, H.S., MacArthur, R.H.: Competition among fugitive species in a harlequin environment. Ecology 53, 749-752 (1972) 
Jalloq, M.C.: The invasion of molehills by weeds as a possible factor in the degeneration of reseeded pasture. I. The buried viable seed population of molehills from four reseeded pastures in West Wales. J. Appl. Ecol. 12, 643-657 (1975)

King, T.J.: Plant ecology of ant-hills in calcareous grasslands. I. Patterns of species in relation to ant-hills in southern England. J. Ecol. 65, 235-256 (1977a)

King, T.J.: Plant ecology of ant-hills in calcareous grasslands. II. Succession on the mounds. J. Ecol. 65, 257-278 (1977b)

King, T.J.: Plant ecology of ant-hills in calcareous grasslands. III. Factors affecting population sizes of selected species. J. Ecol. 65, 279-315 (1977c)

Kneebone, W.R.: Breeding for seedling vigor. In: The biology and utilization of grasses (V.B. Youngner, C.M. McKell, eds.), pp. 90-100. New York: Academic Press 1972

Levin, S.A. : Dispersion and population interactions. Am. Nat. 108, 207-228 (1974)

Levin, S.A.: Population dynamic models in heterogeneous environments. Ann. Rev. Ecol. Syst. 7, 287-310 (1976)

Levin, S.A., Paine, R.T.: Disturbance, patch formation, and community structure. Proc. Nat. Acad. Sci. USA 71, 2744-2747 (1974)

Levins, R., Culver, D.: Regional coexistence and competition between rare species. Proc. Nat. Acad. Sci., USA 68, 1246-1298 (1971)

McKell, C.M.: Seedling vigor and seedling establishment. In: The biology and utilization of grasses (V.B. Youngner, C.M., McKell, eds.), pp. 74-89. New York: Academic Press 1972

Platt, W.J.: The colonization and formation of equilibrium plant species associations on badger disturbances in a tall-grass prairie. Ecol. Monogr. 45, 285-305 (1975)

Platt, W.J., Weis, I.M.: Resource partitioning and competition within a guild of fugitive prairie plants. Am. Nat. 111, 479-513 (1977)

Preston, F.W.: The cannonical distribution of commonness and rarity, part I. Ecology 43, 185-215 (1962a)

Preston, F.W.: The cannonical distribution of commonness and rarity, part II. Ecology 43, 410-432 (1962b)

Rice, E.L.: Growth and floral development of five species of range grasses in central Oklahoma. Bot. Gaz. 111, 361-377 (1950)

Ross, M.A., Harper, J.L.: Occupation of biological space during seedling establishment. J. Ecol. 60, 77-88 (1972)

Salisbury, E.J.: The reproductive capacity of plants, London: Bell 1942

Skellam, J.G.: Random dispersal in theoretical populations. Biometrika 38, 196-218 (1951)

Slatkin, M.: Competition and regional coexistence. Ecology 55, 128-134 (1974)

Spedding, C.R.W.: Grassland ecology. Oxford: Clarendon Press 1971

Stebbins, G.L.: Colonizing species of the native California flora. In: The genetics of colonizing species (H.G. Baker, G.L. Stebbins, eds.), pp. 173-195. New York: Academic Press 1965

Teeri, J.A., Stowe, L.G.: Climatic patterns and the distribution of $\mathrm{C} 4$ grasses in North America. Oecologia (Berl.) 23, 1-12 (1976)

Weaver, J.E.: North American Prairie. Lincoln, Nebraska: Johnsen 1954

deWet, J.M.J., Harlan, J.R.: Weeds and domesticates: evolution in the man-made habitat. Econ. Bot. 29, 99-107 (1975)

Williams, C.B.: Patterns in the balance of nature. New York: Academic Press 1964

Williams, W.A., Black, J.N., Donald, C.M.: Effect of seed weight on the vegetative growth of competing annual Trifoliums. Crop Sci. 8, 660-663 (1968)

Wilson, E.O.: Social modifications related to rareness in ant species. Evolution 17, 249-253 (1963)

Received June 16, 1978 